\title{
A magyar polgári védelem történeti áttekintése
}

DOI : 10.31627/RTF.XXIV.2014.35-36-37-38N.15-24P

Már az ókorban is megvolt a törekvés az emberekben a biztonságra, és úgy a békebeli katasztrófák esetén, mint háborúskodások alkalmával összefogtak a károk megelőzésére, csökkentésére, sőt a szervezett társadalmak állami feladatként gondoskodtak is bizonyos fokon polgáraik védelméről.

A barlangok, pincék óvóhelyként való használata egyidős az emberiséggel. A hegyek közé, erdőkbe menekülés, a létfontosságú javak elrejtése, védőlétesítmények építése sem mai találmány. Az építési elöírásokban megtestesülő biztonság, a magaslatokon való építkezés, a szervezett tüzvédelem, az ivóvízmérgezés szigorú büntetése ezeréves múltra tekint vissza.

\section{A légoltalom létrejöttétől a II. világháború befejezéséig}

Az első világháborúban jelent meg először olyan harci eszköz - a repülőgép — amely mint fegyver lehetővé tette, hogy a harcoló felek egymás hátországát is támadják, bombázzák. Az első légitámadások minden technikai gyengeségük, alacsony hatásfokuk ellenére is egy, a perspektívát tekintve felmérhetetlenül jelentős tényt szentesítettek. Támadhatóvá, bombázhatóvá vált a hadviselö felek által eddig elérhetetlen terület, az arcvonal mögötti hátország.

Ezt a tényt felismerve, közvetlenül az első légitámadásokat követően megszületett a szervezett védelem, a légoltalom.

A rendszeressé vált légitámadások ráébresztették a hadviselö feleket, hogy az addig sérthetetlennek tartott hátország lakossága kiszolgáltatott és védtelen az ellenség légitámadásai ellen. Sürgősen létre kellett hozni a légvédelem mellett egy olyan polgári irányítás alatt álló szervezetet, amely passzív eszközökkel, rendszabályokkal védi a lakosságot. Az Osztrák-Magyar Monarchia közös hadügyminisztere 1916 őszén intézkedett a légoltalom megszervezéséröl. Magyarországon — ahol a távolságok az arcvonaltól még nagyobbak voltak - a honvédelmi miniszter 1917 áprilisában rendelte el, hogy a „A Magyar Királyság azon részein, melyek nem tartoznak a hadra kelt sereghez”, azaz a hátországban, létre kell hozni a „légjárómű elhárító szolgálatot”. A két társország egyesített szolgálatparancsnoksága Bécsben volt, és az egész Osztrák-Magyar Monarchia területén a katonai kerületeknél szervezett szolgálat-parancsnokok útján felügyelte a polgári szolgálat munkáját.

Hazánkban a honvédelemi miniszter 1917-ben kiadott rendeletével intézkedett a légi figyelő és riasztószolgálat megszervezésére és meghatározta a légoltalom feladatait is. Gyakorlatilag tehát a magyar légoltalom elődje 1917-ben született meg. Budapesten ekkor jelentek meg az első falragaszok, amelyek felhívták a lakosság figyelmét a magatartási szabályokra. „,Bár Budapest messze van a harcterektöl—de azért célszerü minden eshetöségre készen lenni..." mondta a falragaszok bevezetö szövege. A Magyar Királyi Belügyminisztérium által közzétett rendszabályok szerint a , légiriadót” kürtjellel, rakétával és telefonhírmondóval rendelték el.

A háborút követően a húszas évek végére, a harmincas évek elejére minden jelentős európai országban létrehozták az első légoltalmi szervezeteket.

Kettős utat járva mind a szélesebb tömegekre támaszkodó társadalmi, mind a hatósági intézkedéseket központi irányításra alkalmas szervezetek általában egyidejüleg és párhuzamosan épültek ki. Az elveket hazánkban a vezető európai államokhoz viszonyítva, néhány év késéssel követték a megvalósítás első lépései.

A Legfelsőbb Honvédelmi Tanács 1932-ben elfogadta a hadsereg távlati fejlesztési tervét. Ebben szerepelt a légierő kiépítése, 48 repülőszázaddal, ${ }^{1}$ a légvédelmi tüzérség fejlesztése és modernizálása, valamint a működőképes figyelö- és jelentőrendszer kiépítése, úgy a katonai, mind a polgári részével. Ez utóbbi rész tekinthető a légoltalom megteremtéséhez vezető előkészületek első lépésének.

1933 novemberében megalakították az Országos Légvédelmi Parancsnokságot, melynek feladata a vezetési és fejlesztési kérdések megoldása, valamint a honi légvédelem megszervezése és kiépítése volt. Úgy a katonai, mint a polgári légvédelmet az alárendeltségébe utalták. Munkájukat a Vezérkar irányelve szabályozta. Az Országos Légvédelmi Parancsnokság nagy lendülettel megkezdte az ország légvédelmének megalapozását. Ekkor még szük törzse hamar kidolgozta javaslatait és terveit a „katonai légvédelmi parancsnokságok” felállítására, az „Országos légvédelmi figyelo és figyelmeztető szolgálat” megszervezésére, valamint elkezdte a „Honi légvédelmi figyelö és figyelmeztetö szolgálat” címü utasítás kidolgozását. A polgári légoltalommal is foglalkoztak. Elkészítették „,A polgári légvédelmi törvény tervezet"-et, a polgári légvédelem kiépítését szabályzó honvédelmi minisztériumi rendelet tervezetet, és előadássorozatot is tartottak, melynek tárgya a légvédelem volt. ${ }^{2}$ A következö évben az Országos Légvédelmi Parancsnokság parancsnoka jogosan jelenthette, hogy ,az aktív légvédelem már meg van alapozva, most a polgárit kell megszervezni." 
A légvédelem megszervezésének fontos lépése volt a hatósági légoltalom megvalósítását előíró, a légvédelemről szóló 1935. évi törvény ${ }^{3}$, illetve a honvédelmi miniszter által 1936. VIII. 6-án kiadott végrehajtási utasítás amely a légoltalmi utasításhoz köthető.

A törvény elöírta, hogy minden a 14. életévét betöltött magyar állampolgár 60. életévéig, nemre való tekintet nélkül, légoltalmi kötelezettség alá esik. Beosztható légoltalmi szolgálatra, hogy kiképzésen, gyakorlaton vegyen részt. Ennek érdekében meghatározott időre mozgási szabadsága korlátozható, és különféle rendelkezések végrehajtására kötelezhető volt. A korlátozásokat a honvédelmi miniszter rendelhette el. A honvédelmi miniszter jogköre lett a városok, községek, legfontosabb üzemek, ipartelepek stb. védelmi fontosságának a megállapítása és sorrendjének a meghatározása.

A törvény meglehetősen drákói büntetőszankciókat írt elő. ,, Aki légitámadás alatt, vagy annak veszélye esetén gondatlanságból megsérti a hatósági rendelkezéseket, 5 évig tartó, aki pedig szándékosan, az 15 évig terjedö fogházzal büntethetö. Az államérdek súlyos megsértése esetén pedig halálbüntetéssel sújtható". ${ }^{4}$

Pontosan meghatározták a légoltalom fogalmát, feladatát és vezetési rendszerét. A honi légvédelmet aktív légvédelemre, az élet- és vagyonbiztonságot oltalmazó passzív védekezésre, azaz a légoltalomra osztották. Mindkét feladatot országos szinten a honvédelmi miniszterre ruházták, aki ezt a tevékenységet az Országos Légvédelmi Parancsnokság útján irányította.

A honvédelmi miniszter a vezérkarral együttmüködve az ország területén a védelmi szempontokat figyelembe véve fontossági sorrendbe állította a katonai, gazdasági, politikai, társadalmi és egyéb létesítményeket, városokat, falvakat.

A miniszter három alapvető kategóriába sorolta a légoltalmi közületeket. Az „A” vagy az I. csoportba a kiemelten fontos városok, a honvédelmi szempontból fontos ipartelepek, a Magyar Királyi Államvasutak, a Magyar Királyi Posta és a Magyar Nemzeti Bank tartoztak.

A „B” vagy a II. csoportba azok a veszélyeztetett városok, községek, ipartelepek kerültek, amelyek a lakosság ellátása, a haditermelés, a közlekedés, a hírközlés szempontjából lényegesek voltak.

A „C” vagy a III. csoportba az összes 10 000-nél nagyobb lélekszámú várost, községet sorolták. A légoltalmat a honvédelmi miniszter irányította, az országos légvédelmi parancsnok útján. A vezető szervezetek mellett létrehozták a légvédelmi jelző- és légvédelmi riasztó szolgálatokat is.

A közületek saját területükön teljes mértékben kötelesek voltak megszervezni, előkészíteni, felépíteni, müködtetni a légoltalmi létesítményeket és szervezeteket. Az ország területét 7 légvédelmi kerületre osztották. A kerületek élén a vegyes dandár-, hadtest- légvédelmi-parancsnokok álltak, akik a légoltalomért is felelősek voltak. Budapesten a föpolgármester, a megyei városokban a polgármester, a megyéknél az alispán, a járásoknál és a járásszékhely községeknél a főszolgabíró, a községeknél a jegyző volt a légoltalmi vezető.

A légoltalom középponti — mondhatni „harcászati szintü” — irányító egysége a város és az üzem volt, mert a várható légitámadások által létrehozott kárhelyek, kárterületek nem lépték túl a városok, üzemek területét. A védekezés és mentés (kárfelszámolás) ennek megfelelően alapvetően lokális jellegü volt.

A légoltalom civil társadalmi szervezete, a Légvédelmi Liga 1937. XII. 5-én alakult meg. Elökészítő bizottsága már 1935-től ülésezett, hivatalos lapja a Riadó először 1937 őszén jelent meg. Az alakuló ülésen részt vett vitéz nagybányai HORTHY Miklós kormányzó és DARÁNYI Kálmán miniszterelnök is. A Légvédelmi Liga elnöke HABSBURG József Ágost tábornagy királyi herceg volt.

A magyar társadalom széles rétegeinek mozgósítását és tájékoztatását követően 1937. XII. 5-én a Vigadóban, vitéz nagybányai HORTHY Miklós kormányzó és DARÁNYI Kálmán miniszterelnök jelenlétében ünnepélyes keretek között megalakult a Légvédelmi Liga. Látszólag szigorú társadalmi szerveződés volt, s az ország közigazgatási tagozódásának megfelelően épült ki. Fő feladata az ország lakosságának légoltalmi felkészítése és a hatósági feladatok társadalmi támogatása volt. A kormányzó egyszerü tagként lépett be a ligába.

A társadalmi háttér azonban a liga félkatonai jellegét álcázta. Feladatait tekintve beletagozódott az ország akkori kiépítés alatt álló, egységes honvédelmi rendszerébe és „,vezérkarába”. A föszerepet aktív, vagy nyugállományú katonatisztek játszották.

A liga vezetője, elnöke HABSBURG József Ágost főherceg, tábornagy volt, az alelnök dr. vitéz FÁBRY Dániel ezredes országos légvédelmi parancsnok, főtitkára TEASDALE Ottó másodföparancsnok, igazgatója PETRÓCZY István nyá. ezredes lett.

József főherceg a Riadó címü lapban megjelent köszöntőjében hangsúlyozza a Légvédelmi Liga sikeres müködéséhez az egység és az összefogás fontosságát. 
A Légvédelmi Liga lapja a „Riadó” jól szerkesztett, középszintű szakmai tájékoztató- és propagandalap volt. Először a „,Riadó” mellékleteként, majd 1939-től önálló szaklapként jelent meg a „Légoltalmi közlemények",

Feladatait tekintve Légvédelmi Liga beletagozódott az ország akkor kiépítés alatt álló egységes honvédelmi rendszerébe.

Rövid idő alatt, 1938 elején a légoltalmi szervezetek, ha felszereltségben és az óvóhely építés színvonalában még nem is, de a többi területen már jelentős mértékben ledolgozták több éves hátrányukat és ha még nem is tudtak felzárkózni az élvonalat jelentő német, angol, szovjet légoltalom színvonalához, a felzárkózást megkezdték és a kisantant államok színvonalát elérték, sőt egyes területen le is hagyták.

Az 1938 márciusában meghirdetett győri program 30 millió pengőt irányozott elő a légoltalom fejlesztésére. 1938 őszétől jelentős óvóhelyépítés kezdődött először Budapesten, majd a II. világháború kitörését követően mindenütt az országban. Az óvóhelyek költségeit részben az állam, részben a főváros, illetve a vidéki elöljáróságok vállalták magukra, részben pedig áthárították a gyárak, lakóházak tulajdonosaira. A magántulajdonosok részére azonban az állam nagyon jelentős adókedvezményt engedélyezett. ${ }^{6}$

1939-ben jelent meg a Légvédelmi Liga „Légoltalmi $A B C$ ” című ingyenes kiadványa, melyet az év májusában és októberében is 1-1 millió példányban nyomtattak ki. Ebben a kiadványban leírásra kerültek a légvédelem és a légoltalom feladatai, a légópincék és az óvóhelyek kialakításának módozatai, a gázbiztosítás, az elsötétítés, és a tűzbiztonsági intézkedések végrehajtása, valamint a légoltalmi pincék felszerelését árusító boltok névjegyzéke.

Nagy hangsúlyt fektettek a harci gázok elleni védekezésre, ennek ékes példája az úgynevezett Népgázálarcok bevezetése, melyeket kereken két fillérért lehetett megvenni a kijelölt boltokban. Ennél is messzebb ment a Légoltalmi Liga, amikor gyüjtéseket rendezett, hogy a legszegényebbeknek is jusson a gázálarcokból. ${ }^{7}$

A honvédelemröl szóló törvény 1939. III. 11-én lépett életbe, és a magyar légvédelmet, illetve légoltalmat is új alapokra helyzete. Ez a törvény mondta ki Magyarországon az általános honvédelmi kötelezettséget, illetve a honvédelmi kötelezettség elvét. A törvény rendelkezései értelmében ugyanis a honvédelmi kötelezettség most már nemcsak a szorosan vett hadkötelezettséget jelentette, hanem egyebek között a levente- és munkaszolgálatot, a személyi és dologi légvédelmi-légoltalmi kötelezettségeket is. ${ }^{8}$ „A légvédelem célja a légitámadások elháritása, a légitámadás elleni védekezés közigazgatási és társadalmi megszervezése, az ország lakosságának a légitámadás elleni védelmére való szakszerü elökészitése és kiképzése, továbbá légitámadásoktól való megvédése, valamint a légitámadás hatásainak csökkentése."

A honvédelmi miniszter minden a légoltalommal kapcsolatos jog- és hatáskört egy kézbe csoportosított. A légoltalom országos vezetését a második világháború éveiben a Magyar Királyi Honvédelmi Minisztérium VI. légoltalmi csoporfönöke vitéz SzURMAY Lajos vezérőrnagy fogta össze.

A légoltalom megelőző szervezetei voltak a helyi légvédelmi figyelő és jelző, riasztó-, elsötétítő és kárfigyelő szolgálatok. A légoltalom kárelhárító és mentő szervezetei voltak a tủzvédelmi, egészségügyi és gázvédelmi, közmü-helyreállító, helyreállító és romeltakarító szolgálatok, valamint segédszolgálatok: segédrendőrök, híradók és a parancsnokságok kiszolgáló állománya. Minden szervezeti egység három váltásból állt.

A támadó ellenséges légi kötelékek, bombázógépek berepülésének észlelése, majd az ország légterében való mozgásának megfigyelése, jelentése a honi légvédelmi figyelö és jelentő szolgálat feladata volt.

A magyar légoltalom a honvédelmi miniszter 1940. V. 18-án kelt rendeletével lett teljes, amely pontosan szabályozta a légoltalmi csoportba tartozó építmények (lakóházak és hasonló elbírálás alá eső épületek) védelmét.

A német csapatok 1941. IV. 6-án hajnalban lépték át Jugoszlávia határait. Még aznap a jugoszláv légierő három bombázógépe Graz felé tartva berepült Magyarország légtérébe és az egyik gép megközelítette Budapestet, ekkor volt Budapest történetében az első éles légi riadó. Másnap légitámadás érte Szeged és Pécs repülőtereit, később bombázták a kelebiai vasútvonalat, Siklós, Zalaegerszeg városát. Körmendet is érte támadás, ahol egy gyermek meg is halt, ő volt a második világháború Magyarország elleni bombatámadásainak első áldozata. 1941 IV. 13-a után — néhány harcászati szintü légi tevékenységet leszámítva - megszüntek a jugoszláv légierő magyarországi célok elleni bomba- vagy fedélzeti fegyverekkel végrehajtott támadásai. 
1941. VI. 22-én hajnalban Németország megtámadta a Szovjetuniót. 1941. VI. 26-án bombák hullottak Kassára. Magyarország, Németország szövetségeseként bekapcsolódott a második világháborúba és ez döntő fontosságú volt a magyar légoltalom szempontjából is. Az első napok néhány, egy-két géppel végrehajtott szovjet légitámadását leszámítva az ország felett egészen 1942 nyaráig teljes csend volt.

Az első komolyabb szovjet légitámadások 1942 szeptemberében történetek. Szeptember 4-éről 5ére virradó éjszaka szovjet távolbombázók bombázták Kispestet, majd 9-10-én újra Budapesten ellen indultak. A repülők a müsorszóró rádióadók alapján tájékozódtak, Budapesten pedig a város hanyag elsötétítése segített bombázáskor. Ezek után mind a honvédelmi, légoltalmi vezetés, mind a lakosság ráébredt, hogy nem lehetnek távoli szemlélői a háborúnak. Megszigorították többek között a lakóházak óvóhelyeinek építését, berendezését.

A németországi repülőgépgyártást és a vasúti közlekedést támadó hadmüvelet sorozathoz kapcsolódó müvelet 1944. IV. 3-án érte el Budapestet és környékét. Bombázták a ferencvárosi rendező pályaudvart, a csepeli WEISS Manfréd repülőgép-motorgyárat és a HORTHY ligeti Dunai Repülögépgyárat. Ez volt a légi hadmüveletek első szakasza.

A második hullám május elejétől nagyjából június 10-ig a kelet-nyugati irányú vasúti közlekedés szétverése volt. Ezzel a június 6-i normandiai partraszállás sikerét akarták biztosítani és megakadályozni a német csapatok nyugatra történő átcsoportosítását. Csúcspontja a június 2-i „Frantic Joe” fedőnevü hadmüvelet volt. Aznap Szolnok, Debrecen, Miskolc, Püspökladány, Szeged, Nagyvárad, Kolozsvár vasútállomását érte nagyon súlyos bombatámadás.

A Magyarország elleni harmadik légi támadás 1944. VI. 8-án valósult meg, a partraszállás sikeres végrehajtását követően. A müvelet során tizenkét nagy erejü támadást hajtottak végre, köztük a legsúlyosabb a július 2-ai Budapest elleni volt. Bombázták a Nyugati pályaudvart egészen az újpesti bejáratig, a ferencvárosi rendező-pályaudvart, valamint a kőolaj-finomítókat.

A bombatámadások megindulása után a légoltalom gyorsan és hatékonyan szervezte meg mindenütt a mentést, kárfelszámolást, a sérültek ellátását és a helyreállítást.

A szervezet 1944. X. 15-ével a nyilas hatalomátvétellel gyakorlatilag széthullott. Az addig jól öszszefogott, hatékonyan müködő magyar légoltalom központi irányítás nélkül maradt, csupán a helyi légoltalmi vezetőségek tudtak beavatkozni egyes helyeken.

\section{A légoltalom a belügyi tárca felügyelete alatt 1948-1962}

Az 1944-ben oly jelentős teljesítményt nyújtó légoltalom a második világháború után teljesen széthullott. Szervezetei közül csupán a temetéseket végrehajtó brigádok müködtek még néhány hétig. A fegyverszünet előírta többek között, hogy Magyarország köteles betiltani, feloszlatni az összes félkatonai szervezetet, köztük a Légoltalmi Ligát is. ${ }^{10}$

A légoltalom újjászervezéséhez egy újabb háborús veszélyhelyzetre volt szükség. A légoltalom újjászervezése már szovjet befolyás mellett valósult meg, a korábbi magyar hagyományoktól eltérően, nem a honvédelmi, hanem a belügyi vezetés alá rendelték az Magyar Dolgozók Pártja Politikai Bizottságának határozata alapján. 1949. X. 18-án minisztertanács részére soron kívül a előterjesztés készült a légoltalom újjászervezésére. ${ }^{11}$

Az elnöki tanács a javaslatot elfogadta és megbízta a belügyminisztert a szervezet megalakításával, melynek jogi alapját a honvédelemröl szóló 1939. évi törvény alkotta. A Magyar Köztársaság légoltalmának irányítását a belügyminiszter a honvédelmi miniszterrel összehangolva, és a szakminiszterekkel egyetértésben látta el. Tehát az újonnan megszervezett légoltalom országos irányítója a belügyminiszter lett, munkáját az 1950 alakult Belügyminisztérium VI. Légoltalmi Főosztály útján végezte. A légoltalom újjászervezésére a második világháborús magyar tapasztalatok és a Szovjetunió egységesítési elvárásai szerint került sor. Ennek megfelelően a hatósági — tehát a közigazgatás felépítését követő - légoltalmi szervezetek mellett, szovjet mintára létrejöttek az államosított ipar, infrastruktúra központosított irányításának megfelelően kiépült népgazdasági (üzemi) légoltalmi szervezetek is.

A háború utolsó éveinek tapasztalata alapján, az eddigi „lokális védelem” helyett a „területi védelem" került elötérbe, melynek keretében a megye lett a légoltalom alapvető vezetési, müködési egysége. A városokat, üzemeket három kategóriába sorolták.

I. kategóriába tartoztak azok a városok, amelyek „hadmüveleti, ipartelepítési, vasúti forgalmat, vagy népsűrüségi szempontból fokozottabb élet- és vagyonvédelmet igényeltek. Itt nagy létszámú felszerelt légoltalmi egységeket kellett szervezni, továbbá lakóházi és nyilvános óvóhelyeket kellett létesíteni. 
Ide sorolták még azokat az üzemeket, melyek hadiipari jelentőségúek voltak, ahol a dolgozók 65 százalékának a legmagasabb szintủ óvóhelyvédelmét biztosították.

II. kategóriába a többi jelentôs várost és az I-be be nem sorolt hadianyaggyártó, valamint a lakosság ellátása szempontjából fontos üzemeket tették. Az itt dolgozók 65 százalékát óvóhelyeken kellett védeni, és olyan légoltalmat létrehozni, mely képes a kisebb károkat önállóan felszámolni.

III. kategóriába sorolták az összes többi üzemet. Az élet- és vagyonvédelmet a lakóházakhoz, lakóközösségekhez kapcsolva kellett megoldani.

1951 májusában megalakult a Központi Légoltalmi Zászlóalj, amely az ország lőszer- és bombamentesítését végezte.

Az 1951-1954-es években a szovjet hadászati elgondolásokon a magyar légoltalom még a hagyományos légitámadó eszközök elleni védekezés elvének megfelelően lokális jelleggel épült ki. A „föszerepet" a sorolt városok és népgazdasági objektumok (üzemek, pályaudvarok, stb.) játszották. A megyék ekkor még az országos irányítás, a Országos Légvédelem Parancsnokságának irányítása és városok közötti transzmissziós szerepkört töltötték be. 1950-ben megalakult a Belügyminisztérium Légoltalmi Országos Parancsnokság.

Feladatai voltak:

- kiépíteni a hatósági légoltalmat, a szakszolgálatok rendszerét;

- kiképezni a felállított szervezetek teljes személyi állományát;

- működőképessé tenni a meglévő óvóhelyeket;

- új, védett létesítményeket építeni;

- elvégezni a tüzszerész feladatokat;

- irányítani az üzemi (népgazdasági) légoltalom, valamint a lakosság önvédelmi rendszerének kiépítését. $^{12}$

Az 1950-es évek közepére a nukleáris fegyverkészletek rohamos növekedése volt jellemzö, mely jelentős hatást gyakorolt a magyar légoltalom több területére is. Az életvédelmi létesítmények tervezése, építése során az építési követelmények között 1955-1956-ban már az atomfegyver hatásai elleni védelem is szerepelt.

Ugyancsak még ebben a kiképzési évben a légoltalom vezető és részben a szakmai állománya részére megkezdődött az rádioaktiv- bakterológiai- és vegyi fegyverekkel kapcsolatos tájékoztató oktatás. A kormány kötelezte a belügyminisztert a légoltalom és a lakosság tömegpusztító fegyverek elleni védelmére való felkészítésének meggyorsítására. Az 1956-os forradalom és szabadságharc eseményei e törekvéseket félbeszakították. A légoltalom a helyreállítási feladatokat végezte.

1953 után a légoltalom új feladatként bekapcsolódott az országot érintő természeti és ipari katasztrófák elleni védekezésbe és a kialakult kárhelyeken történő kárfelszámolásba.

A hidegháború a tömegpusztító fegyverek gyors fejlődése következményeként a megnövekedett követelmények és feladatok szükségessé tették, hogy létrejöjjön az egész országot átfogó védelmi rendszer, amelynek a mindenkori legfontosabb feladata, hogy a lakosság védelme érdekében mozgósítsa a rendelkezésre álló erőket, eszközöket.

Az új követelmények szerint továbbfejlesztendő légoltalomnak három nagy feladatra kellett alkalmassá válnia, mégpedig:

- megszervezni a lakosság védelmét, megteremteni a túlélés feltételeit egy lehetséges rakétaháború esetére;

- a népgazdaság állóképessége biztosítása érdekében megvalósítani a népgazdasági, ipari, mezőgazdasági, kommunális, infrastruktúrális intézmények, létesítmények védelmével kapcsolatos feladatokat, a túlélést biztosító anyagi javak védelmét;

- a tömegpusztító vagy hagyományos fegyverek csapásai által sújtott körzetekben megszervezni és végrehajtani a mentő, mentesító és halaszthatatlan helyreállító munkákat.

A három cél puszta felsorolásából is egyértelmüen kitủnik, hogy csak hatalmas összegü beruházásokkal lehetett volna a feladatokat megvalósítani. Az igazsághoz hozzátartozik, hogy e célkitüzések még a mai napig sem valósultak meg. A fejlesztés célja a légoltalom polgári védelemmé fejlesztése volt, e cél érdekében megvalósuló folyamat 1958 után gyorsult fel.

A hidegháború eseményei meggyorsították a korszerüsítést. ${ }^{13}$

A MSZMP Politikai Bizottsága 1958-ban határozatot hozott a légoltalom továbbfejlesztéséröl, 1960-ban pedig az ország légoltalmi felkészítéséről. Megalakult a Belügyminisztérium Légoltalom Országos Törzsparancsnoksága és ezzel egy időben kiépültek a megyei, városi szakszolgálatok parancsnokságai is. 


\section{Légoltalom a honvédelmi tárca alárendeltségében 1962-1972}

A nemzetközi válság felgyorsította az egész magyar hadseregfejlesztést is. Ebben a helyzetben a Honvédelmi Bizottsága 1962. XI. 1-vel átalárendelte a belügyi tárcától a honvédelmi miniszter alárendeltségébe az egész feladatkomplexumot és szervezetét.

1964-ben az elnöki tanács 1. sz. törvényerejü rendelete elöírta, hogy a „Légoltalom” helyett az új tevékenység célját és jellegét jobban kifejező „Polgári Védelem” nevet kell használni. Megkezdődött a polgári védelmi feladatok újbóli szabályozása.

A polgári védelem fö feladataiként rögzítették:

- Megszervezni a lakosság védelmét, megteremteni a túlélés feltételeit egy lehetséges rakétanukleáris háborúban.

- A népgazdaság állóképessége biztosítása érdekében megvalósítani a népgazdasági, ipari, mezőgazdasági, kommunális, infrastrukturális intézmények, létesítmények védelmével kapcsolatos feladatokat és az anyagi javak védelmét.

- A tömegpusztító fegyverek és hagyományos fegyverek csapásai által sújtott körzetekben megszervezni, végrehajtani a mentő, mentesítő és halaszthatatlan helyreállító munkákat, továbbá közremüködni a természeti és civilizációs katasztrófák elleni védekezésben.

A gyors döntést az is indokolta, hogy szükségessé vált a nukleáris fegyverek elleni védelem összes kérdésének integrálása - a honvédelmi miniszter és a vezérkar irányítása alá —, a feladattal foglalkozó szervezetek tevékenységének céltudatos összehangolása, a szorosan vett honvédelmi követelmények hatékony érvényesítése érdekében. A honvédelmi miniszter, mint a polgári védelem országos parancsnoka jogosítványt kapott arra, hogy a polgári védelmi feladatok eredményes megvalósítása érdekében feladatokat szabhasson a polgári tárcáknak és főhatóságoknak.

Úgy tünhetett, hogy a nemzetközi helyzet kiéleződése helyreállította a légoltalomnak a II. világháborúban, hazánkban jól bevált katonai irányítási rendszerét. De nem erről volt szó. A szovjet katonai doktrínát követtük, egyébként ez volt a Varsói Szerződés doktrínája is. Azt — az egyébként logikus és világszerte a legtöbb országban megtett lépést - tettük, amit a szovjet légoltalom néhány évvel korábban már meglépett. A döntés logikus és helyes volt. A félreértések elkerülése végett leszögezhető, hogy a légoltalom, illetve később a polgári védelem megőrizte szervezeti és hatásköri önállóságát. Nem vált a Magyar Néphadsereg részévé. Költségvetése is önálló maradt. A honvédelmi minisztérium — a vezérkar kivételével — csak a polgári védelem katonai állománya felett rendelkezett.

A honvédelmi miniszter irányításával több döntő jelentőségủ területen 1963-1968 között, több változás jött létre.

A hadsereg egységes szervezeti, müködési és ellátási rendszerébe integrálódtak a polgári védelem alakulatai, melynek nyomán felgyorsult a polgári védelmi ezredek, zászlóaljak szaktechnikával és felszereléssel történő ellátása.

Erre a célra 1961-1965 között a nemzeti jövedelemnek évente átlagosan 0,23\%-át, azaz 5 év alatt 1 milliárd 784 millió forintot fordítottak. Ez azonban csak a ,jéghegy csúcsa” volt. Az igazi fejlődés a szakszolgálatok, önvédelmi szervezetek felkészítésében következett be.

Az új szabályozásnak megfelelően, a polgári védelmi felkészítés alapját a nukleáris fegyverek elleni védelem elveinek, módszereinek tisztázása és kidolgozása alkotta. A 60-as évek végére a polgári védelem gyorsított felkészítésének eredményeként a szakszolgálatokban, önvédelmi szervezetekbe beosztottak létszáma elérte a 700000 föt, az ország lakosságának 7\%-át. A kiképzési ciklus zárásaként több tízezer foót mozgósító megyei nagygyakorlatokra került sor. 1967-ben Borsod-Abaúj-Zemplén megyében 17000 fö, 1968-ban Fejér megyében 25000 fö, Bács-Kiskun-Bodrog megyében 38000 fö, majd 1969-ben Hajdú-Bihar megyében 80000 ember vett részt a gyakorlatokon.

A polgári védelem meghatározó szerepet kapott a katasztrófavédelemben is. 1970 nyarán a felsőtiszai árvíz tapasztalatai bizonyították, hogy a magyar polgári védelem mind országos szinten, mind fővárosi, megyei szinten olyan erős és felkészült, jól funkcionáló vezetési lépcsőkkel rendelkezett, amelyek képesek voltak az országos méretü, öt megyét érintő természeti katasztrófa, és mintegy 80 000 főnyi lakosság mentését, ellátását, kitelepítését, elhelyezését, stb. szervezni és végrehajtani. Mintegy 26000 fö polgári védelmi katonai, szakszolgálati és önvédelmi állomány dolgozott a mentö, fertőtlenítő és helyreállító munkák során.

Az 1970. évi árvíz arra is ráirányította a figyelmet, hogy a háborús veszély mellett, sokkal fenyegetőbbek azok a természeti és civilizációs katasztrófák, amelyekkel szemben szintén meg kell védeni a lakosságot. Ennek a felismerésnek a helyességét bizonyítják azok a tények, hogy a két világrendszer között csökkent a katonai ellenállás, megkezdődtek a fegyverzetcsökkentési tárgyalások, valamint az 
atomfegyverek leszerelésének és kivonásának folyamata. Az ipar rohamos fejlődése miatt viszont, egyre több ipari balesettel, és katasztrófával kellett az embereknek és a társadalomnak szembenéznie.

\section{A polgári védelem a Magyar Néphadsereg Hátországvédelmi Parancsnokságának rendszerében 1972-1988}

Adott volt tehát egy olyan begyakorolt, összekovácsolt szervezet, amely az egységes hátországvédelem alapjául szolgálhatott volna, amelyre építve, azt megfelelően tovább fejlesztve, létrejöhetett volna a reális lehetősége a polgári védelem és a katonai védelem integrálásának.

Nem ez történt. A polgári védelem katonai szervezeteit, alakulatait teljesen, a megyei törzsek létszámát pedig mintegy 45\%-al csökkentették, és az újonnan megalakuló Magyar Néphadsereg Hátországvédelmi Parancsnokság rendszerébe építették be.

Az átalárendelés és az új szervezet — Hátországvédelmi Alakulatok Parancsnoksága — létrehozásának folyamata hónapokig tartó személyügyi munkát jelentett és 1973. I. 1-ével fejeződött be. Megtörtént a polgári védelem ,profiltisztítása”. A továbbiakban a polgári védelem - a vezetést biztosító 24 század kivételével - katonai erővel nem rendelkezett, szervezetéhez csak polgári szervezetek, a szakszolgálatok, szolgálatok és önvédelmi szervezetek tartoztak.

A Hátországvédelmi Alakulatok Parancsnoksága belépésével értelemszerüen együtt járt a feladatok ismételt szabályozása, a jog- és hatáskörök újbóli megfogalmazása. Ennek keretében újra kellett fogalmazni az ország védelmi rendszerében a polgári védelem célját, helyét, szerepét, feladatait, fejlesztésének irányait és pénzügyi lehetőségeit. A jogi keretek az 1974. évi polgári védelemről szóló minisztertanácsi, illetve honvédelmi miniszteri végrehajtási utasítás töltötte meg tartalommal.

1977. XII. 13.-án Genfben, a Magyar Népköztársaság kormánya külügyminisztériumának megbízottja aláírta — 46 ország kormányának képviselöjével együtt — az 1949. évi négy genfi egyezmény kiegészítésére alkotott két jegyzőkönyvet, és vállalta, hogy a jegyzökönyvben foglaltakat a hazai magyar belső jogrend részévé teszi. A jegyzőkönyvek szabályozták a polgári védelem helyét és szerepét a nemzetközi hadijogban. A jegyzőkönyv szerint a polgári védelem fogalma alatt értendő minden olyan humanitárius feladat, amelynek a célja, hogy védelmet nyújtson a polgári lakosságnak az ellenségeskedés, háborús cselekmények, illetőleg a katasztrófák esetén, és segítse azok közvetlen hatásainak leküzdésében, illetve a túlélés feltételeinek a biztosításában. Tételesen részletezik, melyek a polgári védelmi feladatok.

A jegyzőkönyvek intézkedtek a Vöröskereszthez hasonlóan a polgári védelmi feladatot ellátó személyek, személyzetek nemzetközi hadijogban szabályozott védelmére.

1976-ra teremtődtek meg a feltételek egy új polgári védelmi kiképzőbázis megszervezésére. Budapesten, a Ferihegyi úton alakult meg a Polgári Védelmi Kiképző Központ, illetve országszerte jól felszerelt kiképző bázisok alakultak. Az 1976-1988 között új óvóhelyek épültek, amelyek a tömegpusztító fegyverek összes hatása ellen védelmet nyújtottak. Ezek a következők voltak:

- Pakson az atomerőmüben egy 600 fös, egy 300 fös és egy 450 fös óvóhely;

- Dunaújvárosban, a Dunai Vasmüben egy 600 fős, és a kokszolómüben egy szintén 600 fős óvóhely;

- Székesfehérvárott, a Videotonban két 600 fős óvóhely;

- Esztergomban egy 600 fös lakossági óvóhely;

- Budapesten, a Medicor Mủveknél 600 fős, a Budapesti Lakásépítő Vállalat Jászberényi úti telepén két 300 fős, a Hungária Vegyiműveknél egy 600 fös óvóhely;

- Miskolcon, a Lenin Kohászati Müvek területén 450 fós óvóhely;

- Debrecenben, 2000 fős befogadóképességű földalatti garázs óvóhely épült.

Az 1980-as évek elején a vezetésben változások következtek be. A magyar polgári védelem ekkor jelentős mértékben nyitott mind a szocialista, mind a szomszédos, majd a nyugati országok felé is. Ezek már az enyhülés évei voltak.

1986. IV. 26-án, az eddigi idők legsúlyosabb nukleáris — atomerőmüi — katasztrófája következett be, az ukrajnai Csernobilben, melynek következményei egész Európát, közte hazánkat is érintették. Az akkori - politikai és gazdasági - megfontolások szerint a hivatalos tájékoztatás igyekezett a történteket is, a következményeket is elbagatellizálni.

Valóságban a magyar polgári védelem vezetői és beosztottai, az érintett gazdasági ágazatoknál szervezett szakszolgálatok szakembereinek megfeszített, több hónapos munkája tette lehetővé a helyzet „kezelését”.

Ugyanakkor egy jelentős tanulsága volt a történetnek: nem a — remélhetőleg soha be nem következő - nukleáris világháborúra, hanem sokkal inkább a bármikor bekövetkezhető civilizációs és ter- 
mészeti katasztrófák elhárítására kell elsősorban felkészülni, felkészíteni az embereket, a polgári védelem egészét. A szükségszerü változások lassan, erjedésszerüen, de megindultak.

Az ígéretes induló átalakulást, amelynek célja volt zökkenőmentesen átvezetni a polgári védelmet a környező világban végbement politikai és katonai változások következtében elöállott új követelmény rendszerbe, szinte átmenet nélkül vágta ketté a Magyar Szocialista Munkáspárt Politikai Bizottságának 1987. XI. 17-ei határozata, amely kimondta: ,, a két terület racionalizálása érdekében a Hátországvédelmi Parancsnokság és a Polgári Védelem Országos Parancsnoksága egyidejü megszüntetésével, azok bázisán - a Honvédelmi Minisztérium közvetlen irányítása alatt - a hátországi és polgári védelmi feladatok szervezésére, végrehajtására 1988. július 1-ével, középszintü egységes parancsnokságot kell létrehozni”. Így jött létre Hátországi és Polgári Védelmi Parancsnokság.

\section{Szemléletváltás a polgári védelemben 1990-2000}

Az átszervezés időszakában a fő feladat a polgári védelmi felkészítés és a katasztrófák elleni védekezés volt. A rendszerváltást követő első időkben megkérdőjeleződött a polgári védelem szükségessége, felmerült a szervezet felszámolása, de végül döntés született a fennmaradásáról.

Hazánk által 1989 októberében ratifikált és kihirdetett 1949. évi genfi egyezménynek 1. és 4. kiegészítő jegyzőkönyve kimondja a polgári védelem humanitárius jellegét, és azt határozottan elkülöníti a fegyveres erőktől.

Az ezekbe foglalt elvek szükségessé és indokolttá tették a polgári védelem irányítási rendszerének módosítását oly módon, hogy az jobban illeszkedjék az államigazgatás korszerüsített rendszeréhez. Ezért, illetve az új védelmi doktrína megvalósításával összhangban a minisztertanács 1989. XI. 30-án határozatot hozott a polgári védelem országos irányításának a megváltoztatásáról. A minisztertanács határozatában úgy rendelkezett, hogy a polgári védelem országos irányítását a továbbiakban a belügyminisztérium látja el, ennek átadásáról folyamatosan gondoskodni kell. Az érintett minisztériumoknak és országos hatáskörü szervezeteknek a polgári védelem müködését és szervezeti rendjét a belügyi tárca bevezetésével - a készülő önkormányzati törvényre is figyelemmel — át kellett tekinteni, törekedve a racionálisabb, gazdaságosabb megoldásokra.

Rendeltetésében ugyanakkor hangsúly-átrendeződés történt: a feladatkörébe markánsan megjelent a lakosság és az anyagi javak katasztrófák során történő védelme A belügyminisztérium alárendeltségébe történő átmenet 1990. VI. 30-ával nem történt zökkenőmentesen.

A belügyi tárca vezetése nem tudta megtalálni a polgári védelem helyét a tárcán belül, ezért idegen test maradt. Bizonyítja ezt az is, hogy 1993-ban újabb integrációt kellett megélnie a szervezetnek.

Megalakult a Túz- és Polgári Védelmi Országos Parancsnokság, ahol újfent nem a polgári védelem játszotta a vezető szerepet.

1995. III. 21-én a Magyar Köztársaság Alkotmánybírósága az alábbi határozatot hozta: „, . . a $a z$ Alkotmánybiróság megállapitja, hogy a tüzvédelem és a polgári védelem központi irányitásáról szóló 85/1993. (VI.1.) Kormányrendelet, a Polgári Védelemről szóló 15/1992. (I.27.) Kormányrendelet, az ennek védelméröl szóló már hatályon kívül helyezett 1976. évi I. törvény végrehajtása tárgyában megjelent 6/1976. (IV.31.) MT. rendelet alkotmányellenes. Az Alkotmánybíróság az említett rendeletek megsemmisitésére irányuló eljárást 1995. december 31-ével felfüggeszti. "14

Az Alkotmánybíróság az alkotmányellenes jogszabályok megsemmisítésére vonatkozóan az eljárást a rendelkező részben írtak szerint felfüggesztette. Ezzel módot kívánt adni a jogalkotóknak arra, hogy a rendelkezésre álló idő alatt az alkotmányellenes helyzetet szüntessék meg a polgári védelemre, mint alkotmányos alapkötelezettségre vonatkozó joganyagnak az alkotmánnyal és a Honvédelmi törvénnyel való összhangját teremtsék meg.

Az Alkotmánybíróság döntésének megfelelően 1996. I. 1-ével ismételten megalakult a BM Polgári Védelem Országos Parancsnoksága. Ezt követően megjelent a polgári védelemről szóló 1996. évi törvény, amely rendezte a polgári védelem helyét, szerepét, feladatait. ${ }^{15}$ Ilyen szintủ és hatású jogszabály a polgári védelem (légoltalom) 5 évtizedes történetében nem foglalkozott a szervezet tennivalóival. Azonban ez az önálló parancsnokság sem volt hosszú életủ. Újabb integráció következett be, és megint a tủzoltósággal. 1999-ben megjelent a katasztrófák elleni védekezés irányításáról, szervezetéről és a veszélyes anyagokkal kapcsolatos súlyos balesetek elleni védekezésről szóló törvény. E törvény elöírásának megfelelően 2000. I. 1-ével megalakult a BM Országos Katasztrófavédelmi Főigazgatóság. ${ }^{16}$

A 2000. I. 1-jén hatályba lépő katasztrófavédelmi törvény lehetővé tette az egységes hazai katasztrófavédelmi rendszer létrehozását, és a törvényalkotók e jogszabályban rögzítették a „katasztrófák elleni védekezés" fogalmát és elveit is. Ez a meghatározás a katasztrófavédelem komplexitását tükrözi, összetettsége kellően bizonyítja a védelmi és a reagálási képesség fontosságát, valamint azt, hogy a si- 
keres védekezés csak a teljes társadalom és gazdaság összehangolt együttmüködésével valósítható meg. ${ }^{17}$

A katasztrófavédelmi törvény 2011. évi módosításával megteremtődött az alapja a hazai egységes katasztrófavédelem végleges kiépítésének. (I.sz. melléklet)

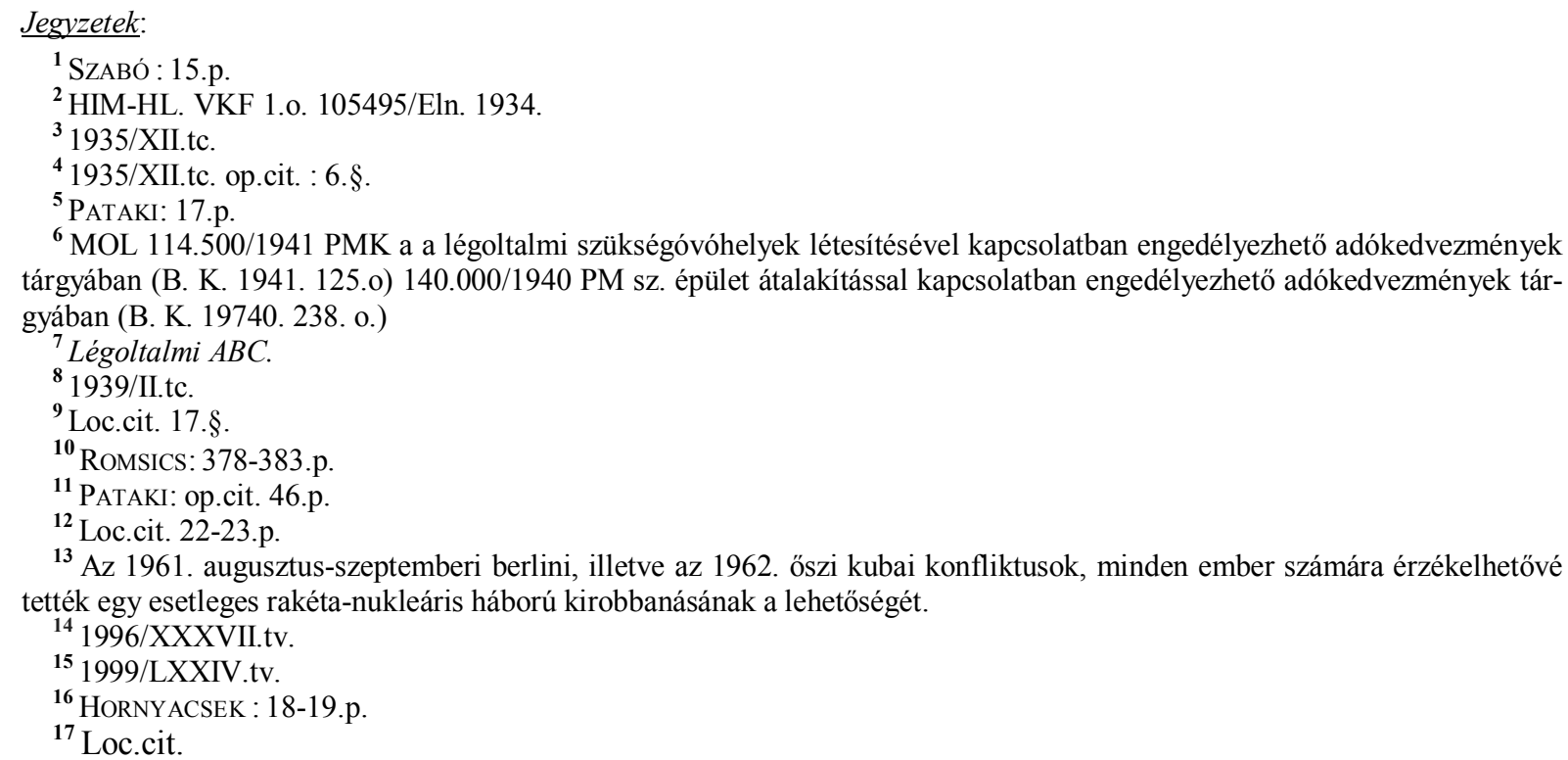

Jegyzetekben alkalmazott röviditések:

\section{MONOGRÁFIÁK, KISMONOGRÁFIÁK ÉS HASONLÓ JELLEGÜ KÖTETEK}

HORNYACSEK

- HoRnyACSEK Júlia: A települési védelmi képességek a katasztrófa kihívások tükrében, a települések katasztrófa-elháritási feladatai, a végrehajtáshoz szükséges helyi védelmi képesség alapvetö területei, azok kialakitásának folyamata. Budapest, 2011, „Biztonságunk érdekében” Oktatási- és Tanácsadó Tudományos Egyesület. 100 p. HU- ISBN 9789630826068.

PATAKY

PATAKI Iván: A Magyar Polgári Védelem (légoltalom) története 1935-1992. Budapest, 1992, PVOP. 138 p. HU-ISBN 9630333961.

SZÖVEGGYÜJTEMÉNYEK

ROMSICS

- Romsics Ignác (szerk.): Magyar Történeti Szöveggyüjtemény 1914-1999. Budapest, 2000, Osiris, I.köt. 531 p. HU-ISBN 9633797829.

KÉZIRATOK

SZABÓ

- Szabó Miklós: A Magyar Királyi Légierő technikai és szervezeti fejlödése (1938-1944). Hadtudományi doktori disszertáció (ZMKA) Kézirat. Budapest, 1981.

\section{LEVÉL-, IRAT-, ÉS DOKUMENTUMTÁRAK}

HIM-HL. $\quad$ - Hadtörténeti Intézet és Múzeum Hadtörténelmi Levéltár

MOL.

\section{TÁJÉKOZTATÓK}

Légoltalmi $A B C$.

\section{JOGSZABÁLYOK}

1935/XII.tc.

- Magyar Országos Levéltár.

1939/II.tc.

1996/XXXVII.tv.

1999/XXIV.tv.

- Légoltalmi ABC. A Légoltalmi Liga ingyenes tájékoztatója.. Budapest, 1939, A légoltalmi liga országos elnöksége. 64 p.

- 1935/XII.tc. a légvédelemröl.

- 1939/II.tc. a honvédelemröl.

- 1996/XXXVII.tv. a polgári védelemről.

— 1999/XXIV.tv. a Katasztrófák elleni védekezés irányításáról, szervezetéről és a veszélyes anyagokkal kapcsolatos súlyos balesetek elleni védekezésröl. 
A magyar polgári védelem szervezetei 1933-2013.

1. Országos Légvédelmi Parancsnokság (1933. V. 1.)

2. Légvédelmi Liga.

3. Belügyminisztérium VI. Légoltalmi Főosztály,

majd

4. Légoltalmi Országos Parancsnokság.

5. Belügyminisztérium Légoltalom Országos Törzsparancsnokság

6. Polgári Védelem

7. Magyar Néphadsereg Hátországvédelmi Parancsnokság rendszerébe integrálták.

8. Belügyminisztérium Polgári Védelem Országos Parancsnokság.

9. Belügyminisztérium Tűz- és Polgári Védelem Országos Parancsnokság.

10. Belügyminisztérium Polgári Védelem Országos Parancsnokság (1996. I. 1.)

11. Belügyminisztérium Tüz- és Polgári Védelem Országos Parancsnokság .

12. Belügyminisztérium Országos Katasztrófavédelmi Főigazgatóság 